\title{
Low Doses of Cadmium Chloride and Methallothionein-1-Bound Cadmium Display Different Accumulation Kinetics and Induce Different Genes in Cells of the Human Nephron
}

\author{
Dana Cucu Patrick C. D'Haese Annelies De Beuf Anja Verhulst \\ Laboratory of Pathophysiology, Faculty of Veterinary, Biomedical, and Pharmaceutical Sciences, \\ University of Antwerp, Antwerp, Belgium
}

\section{Key Words}

Cadmium $\cdot$ Cd7MT-1 $\cdot$ HO-1 $\cdot$ Human tubular cells $\cdot$ MT-1

\begin{abstract}
Background/Aims: The present study was conducted to investigate the renal tubular handling of inorganic cadmium $\left(\mathrm{Cd}^{2+}\right)$ by exposing primary human tubular cell cultures to physiologically relevant doses of cadmium chloride $\left(\mathrm{CdCl}_{2}\right)$. Furthermore, the cellular accumulation of $\mathrm{Cd}^{2+}$ was compared to that of metallothionein-1-bound Cd (Cd7MT-1). Finally, this study aimed to investigate the effect of the accumulation of $\mathrm{Cd}$ (both $\mathrm{Cd}^{2+}$ and $\mathrm{Cd}$ 7MT-1) in renal cells on the expression of genes relevant to nephrotoxic processes. Methods: $\mathrm{Cd}$ concentration was measured using atomic absorption spectrometry. mRNA expression was evaluated by quantitative realtime RT-PCR. Results: $\mathrm{Cd}^{2+}$ accumulated into human tubular cells in a concentration- and timedependent way. Furthermore, cellular accumulation of $\mathrm{Cd}^{2+}$ was different from the cellular accumulation of Cd7MT-1, indicative for different uptake routes. Finally, mRNA expression of the genes encoding the anti-oxidative proteins metallothionein-1 (MT-1) and heme-oxygenase-1 $(\mathrm{HO}-1)$ as well as the pro-apoptotic $\mathrm{Bcl}$-2-associated $\mathrm{X}$ protein (Bax) were upregulated by $\mathrm{CdCl}_{2}$ and not by Cd7MT1. Conclusion: In the presence of physiologically relevant $\mathrm{Cd}$ concentrations, tubular accumulation of the element in its inorganic form is different from that of Cd7MT-1. Furthermore, the tubular accumulation of inorganic $C d$ induces mRNA expression of genes of which the protein products may play a role in Cd-associated renal toxicity.
\end{abstract}

Copyright $\odot 2011$ S. Karger AG, Basel 


\section{Introduction}

Cadmium (Cd) is one of the most toxic metals present in our environment. Major sources of $\mathrm{Cd}$ exposure include contaminated food and water, industrial fumes and dusts [1], but cigarette smoke is by far the largest source of $\mathrm{Cd}$ exposure in the general human population [2]. Each cigarette may contain 1-2 $\mu \mathrm{g}$ of $\mathrm{Cd}$, and $40-60 \%$ of the $\mathrm{Cd}$ in inhaled smoke generally passes through the pulmonary epithelium into systemic circulation $[3,4]$.

In humans and other mammals, increased exposure to $\mathrm{Cd}$ adversely affects a number of organs and tissues, including the kidneys, liver, lung, pancreas, testis, placenta, and bone. Out of these, the effect on the kidneys is the earliest and most important and consists primarily of tubular damage and concomitant low-molecular-weight proteinuria [5-9]. In fact, based on epidemiological and toxicological studies in humans and investigations in animals, the International Agency for Research on Cancer (IARC) has classified Cd as a Category I carcinogen (IARC, 1993).

Environmental/occupational exposure to the non-essential metal Cd, together with various other elements such as lead, mercury and arsenic, is a known hazard to human health. The first reliable information on Cd levels in humans originates from studies in the seventies together with the availability of instrumentation and techniques allowing accurate measurement of the low concentrations in which the element circulates in the blood compartment or accumulates in tissues. Already in 1979, Lauwerys et al. [10] reported that blood Cd levels up to $0.1 \mu \mathrm{M}(11.2 \mu \mathrm{g} / \mathrm{l})$ in workers chronically exposed to Cd correlated with an increased risk for renal dysfunction, predominantly of tubular origin. Normal whole-blood Cd levels in the general population have been reported to be $<0.02 \mu \mathrm{M}(2.25 \mu \mathrm{g} / \mathrm{l})$. In 1990, Minoia et al. [11] reported normal-blood Cd levels ranging from 0.005 to $0.05 \mu \mathrm{M}(0.56$ up to $5.6 \mu \mathrm{g} / \mathrm{l})$ in the healthy European population. Significantly elevated values were found in occupationally exposed workers and in people living in the proximity of Cd-processing industries, particularly in smokers $[12,13]$. Most of the in vitro and experimental studies investigating the toxic effects of $\mathrm{Cd}$ were performed in the presence of $\mathrm{Cd}$ concentrations that were orders of magnitude higher than those encountered in vivo.

$\mathrm{Cd}$ taken up via inhalation and/or ingestion undergoes hepatic conversion into the $\mathrm{Cd}$ metallothionein (Cd7MT-1) complex. Cd7MT-1 (MW: 3,500-14,000 Da) is filtered by the glomerulus and taken up by the proximal tubular cells via receptor-mediated endocytosis (RME). However, arguments exist that also inorganic (free ionic) $\mathrm{Cd}\left(\mathrm{Cd}^{2+}\right)$ plays a substantial role in renal toxicity. In this context, the finding that $\mathrm{Cd}$ bound to small peptides may be released at the brush border after which it is taken up in its free ionic form by renal cells is of particular interest [14]. Furthermore, besides affecting the paracellular transport of essential divalent cations $[14,15]$, tubular damage caused by $\mathrm{Cd}$ diminishes the active transcellular transport of $\mathrm{Na}^{+}$and $\mathrm{K}^{+}[16]$. Cd exposure has also been associated with increased urinary calcium $\left(\mathrm{Ca}^{2+}\right)$ excretion and renal stone formation, which can be the consequence of a Cdinduced bone pathology either manifested by an increased calcium efflux out of the bone, a decreased incorporation of the element into the bone [17], and/or blockage of the epithelial calcium channels [18]. In view of these findings, it seems reasonably that inorganic Cd, along with the methylated form, is taken up by renal tubular cells.

Little is known concerning the renal (tubular) handling of $\mathrm{Cd}$ in its inorganic form $\left(\mathrm{Cd}^{2+}\right)$, and although it probably accounts for only a minor fraction of the renal Cd uptake in vivo, studying tubular handling of inorganic $\mathrm{Cd}$ is of particular interest in view of its potential toxicity.

The present study was conducted to investigate the renal tubular handling of $\mathrm{Cd}^{2+}$ by exposing primary human tubular cell cultures to physiologically relevant doses of $\mathrm{Cd}^{2+}(\mathrm{ad}-$ ministered as $\mathrm{CdCl}_{2}$ ). Furthermore, the cellular accumulation of $\mathrm{Cd}^{2+}$ was compared to that 
of Cd7MT-1 and, finally, this study aimed to investigate the effect of the accumulation of Cd (both $\mathrm{Cd}^{2+}$ and MT complexes) in renal cells on the expression of several genes relevant to nephrotoxic processes.

\section{Materials and Methods}

Isolation, Purification and Cultivation of Primary Human Kidney Tubular Cells

Human kidney tubular epithelial cells were isolated as described previously [19]. Briefly, normal human kidney tissue that became available through nephrectomy performed upon oncological indication was collected and processed in a sterile manner. The cortex and outer stripe of outer medulla were dissected, cut into pieces of about $1 \mathrm{~mm}^{3}$ and digested in collagenase D solution (Roche, Ottweiler, Germany). The suspension was shaken vigorously for $2 \mathrm{~h}$ at $37^{\circ} \mathrm{C}$ and sieved through a $120-\mu \mathrm{m}$ sieve. The resulting cell suspension was loaded on top of a discontinuous Percoll (Amersham Pharmacia Biotech, Uppsala, Sweden) gradient with densities of 1.04 and $1.07 \mathrm{~g} / \mathrm{ml}$. After centrifugation tubular cells were carefully aspirated from the intersection, washed, and brought into culture. Cells were seeded in 24 -well plates (25,000 cells/well) in $\alpha$-MEM medium (Life Technologies, Rockville, Md., USA) modified according to Gibson d'Ambrosio, supplemented with $10 \%$ fetal calf serum and grown until confluence ( \pm 6 days). Twenty-four hours before studying the $\mathrm{Cd}^{2+}$ uptake, the serum-containing medium was replaced by serum-free $\alpha$-MEM Gibson d'Ambrosio.

\section{Measurement of the Cellular Cd Concentration}

Cell cultures were exposed to $\mathrm{CdCl}_{2}$ dissolved in $\alpha$-MEM medium $\left(37^{\circ} \mathrm{C}\right)$ at different concentrations $(0-1,000 \mathrm{nM})$ for $5 \mathrm{~h}$. Furthermore, cell cultures were exposed to $\mathrm{CdCl}_{2}$ or Cd7MT-1 (Bestenbalt, Tallinn, Estonia) for different time periods (3-72 h) at $500 \mathrm{nM}$ (for both compounds, concentrations correspond to the metal concentration).

After incubation, cells were extensively rinsed with PBS (3 times) and lysed during 20 min with $0.1 \%$ Triton X-100 in PBS. The lysate was divided in aliquots and stored at $-20^{\circ} \mathrm{C}$ (some aliquots were also stored at $-80^{\circ} \mathrm{C}$ for gene expression studies).

At the time of analysis, $0.5 \mathrm{ml}$ of the lysates were digested in ultrapure $\mathrm{HNO}_{3}($ Merck Suprapur 4371 ) at $70^{\circ} \mathrm{C}$ for $24 \mathrm{~h}$. Digests were subsequently mixed with a matrix modifier consisting of diammonium hydrogen phosphate $(0.5 \mathrm{~g} / 100 \mathrm{ml})$, magnesium nitrate $[0.24$ $\mathrm{g} / 100 \mathrm{ml}$ and Triton X-100 $(0.1 \% \mathrm{~m} / \mathrm{v})]$. The Cd concentration was measured against a matrix-modified aqueous calibration curve with standards prepared from a stock solution of $1,000 \mu \mathrm{g} / \mathrm{ml} \mathrm{Cd}$ (Merck Titrisol 9960) and using a Zeeman 3030 atomic absorption spectrometer equipped with an HGA graphite furnace, an AS-60 autosampler, and an Anadex DP-9500B silent scribe printer, all from Perkin-Elmer (Norwalk, Conn., USA).

In order to evaluate the cellular response to the anti-oxidant compound ebselen, the latter compound was added to serum-free $\alpha$-MEM at a $10 \mu \mathrm{M}$ concentration for $1 \mathrm{~h}$. Cells were then washed 3 times with serum-free medium and were exposed to different $\mathrm{CdCl}_{2}$ concentrations (in the absence of ebselen) for $5 \mathrm{~h}$.

To check the effect of zinc ( $\mathrm{Zn}$ ) on cellular $\mathrm{Cd}^{2+}$ uptake, $5 \mu \mathrm{M} \mathrm{ZnCl}_{2}$ was administered to confluent monolayers $1 \mathrm{~h}$ before addition of $500 \mathrm{nM} \mathrm{CdCl}_{2}$. $\mathrm{Cd}^{2+}$ uptake was then assessed (still in the presence of $\mathrm{Zn}$ ) after 1, 5, and $20 \mathrm{~h}$.

To evaluate the effect of $\mathrm{pH}$ on $\mathrm{Cd}^{2+}$ uptake, parallel experiments were performed in glucose-containing HEPES or 2-(N-morpholino)ethanesulfonic acid (MES) solutions buffered at $\mathrm{pH} 7.4$ and 5.5 , respectively, for $1,5,15$, and $20 \mathrm{~h}$. 
In order to allow the cellular Cd concentration to be expressed per milligram protein, the protein concentration of the cell lysates was determined using a BCA kit (Perbio, Belgium) according to the manufacturer's instructions.

\section{RNA Isolation and Quantitative Real-Time RT-PCR Analysis}

Total RNA was extracted from cell lysates using the RNeasy Micro Kit (Qiagen, Hilden, Germany). cDNA was synthesized using the High-Capacity cDNA Archive Kit (ABI, Nieuwerkerk a/d IJssel, The Netherlands), and mRNA expression was evaluated by quantitative real-time PCR on the ABI Prism 7000 Sequence Detection System (ABI) using the fluorescent Taqman methodology. Ready-to-use primer and probe sets were pre-designed by Applied Biosystems for the following genes: divalent metal transporter 1 (DMT-1; Hs00167206_m1), metallothionein-1 (MT-1; Hs00831826_s1), heme-oxygenase-1 (HO-1; Hs00157965_m1), B-cell CLL/lymphoma 2 (Bcl-2; Hs00153350_m1), and Bcl-2-associated X protein (Bax; Hs99999001_m1). Instructions of the supplier were followed for PCR conditions, which were uniform for all assays under study. The relative mRNA expression of the different genes was analyzed in triplicate, normalized against glyceraldehyde 3-phosphate dehydrogenase (GAPDH; Hs99999905_m1) as a control housekeeping gene and expressed in relation to a calibrator sample using the comparative Ct method. Control (untreated) cells served as calibrator sample which was given a gene of interest/GAPDH mRNA expression ratio value of 1 .

\section{Statistics}

Data are expressed as the means \pm SEM. To analyze saturation curves, non-linear regression was fitted to a Michaelis-Menten equation using OriginLab version 8. Differences in Cd uptake and mRNA levels were tested for significance using the non-parametric Kruskal-Wallis test for multiple group comparison, followed by the Mann-Whitney $U$ test for comparisons between 2 groups using SPSS Statistics 17.0 software.

\section{Results}

Intracellular Cd Accumulation in Primary Human Tubular Kidney Cells

We first examined whether physiologically relevant concentrations of $\mathrm{Cd}^{2+}(0,20,100$, 200 , and $500 \mathrm{nM}$ of $\mathrm{CdCl}_{2}$ ) are taken up by renal tubular cells during an incubation time of $5 \mathrm{~h}$. The dose-response curve depicted in figure la shows that the accumulation of $\mathrm{Cd}$ in the tubular cells is saturable, with a maximal cellular uptake of $641 \pm 76 \mathrm{pmol} \mathrm{Cd} / \mathrm{mg}$ protein.

Figure $1 \mathrm{~b}$ shows the kinetics of intracellular $\mathrm{Cd}$ accumulation by confluent cells incubated with serum-free culture medium containing $500 \mathrm{nM} \mathrm{CdCl}_{2}$ in function of time (filled circles curve). Cellular Cd rapidly increased with time and more or less reached a plateau after $24 \mathrm{~h}$ with a maximal value of $772 \pm 354 \mathrm{pmol} / \mathrm{mg}$ protein after $72 \mathrm{~h}$ of exposure. We performed concomitant measurements of the Cd concentration in the extracellular medium. During $72 \mathrm{~h}$ of exposure and in line with the cellular uptake, the Cd concentration in the extracellular medium gradually decreased to $21.5 \pm 2 \mathrm{pmol} / \mathrm{mg}$ protein. The time-dependent intracellular accumulation of $\mathrm{Cd}^{2+}$ was compared to that of Cd7MT-1 (500 nM; open circles curve). The final amount of $\mathrm{Cd}$ present in the tubular cells after $72 \mathrm{~h}$ of incubation, as well as the accumulation kinetics with either $\mathrm{CdCl}_{2}$ or Cd7MT-1 were significantly different. Whilst the $\mathrm{Cd}$ concentration in cells treated with inorganic $\mathrm{CdCl}_{2}$ reached a plateau after $24 \mathrm{~h}$ of incubation ( $\mathrm{p}>0.05$ between values noted after 24,48 , or $72 \mathrm{~h}$ of exposure), addition of Cd to the culture medium in the Cd7MT-1 complex resulted in a linear and steady increase in the Cd levels from $5 \mathrm{~h}$ ( $\mathrm{p}<0.05$ vs. 24,48 , and $72 \mathrm{~h}$ ) until $72 \mathrm{~h}$ of exposure, reaching a maximal cellular concentration of $407 \pm 28 \mathrm{pmol} / \mathrm{mg}$ protein. 


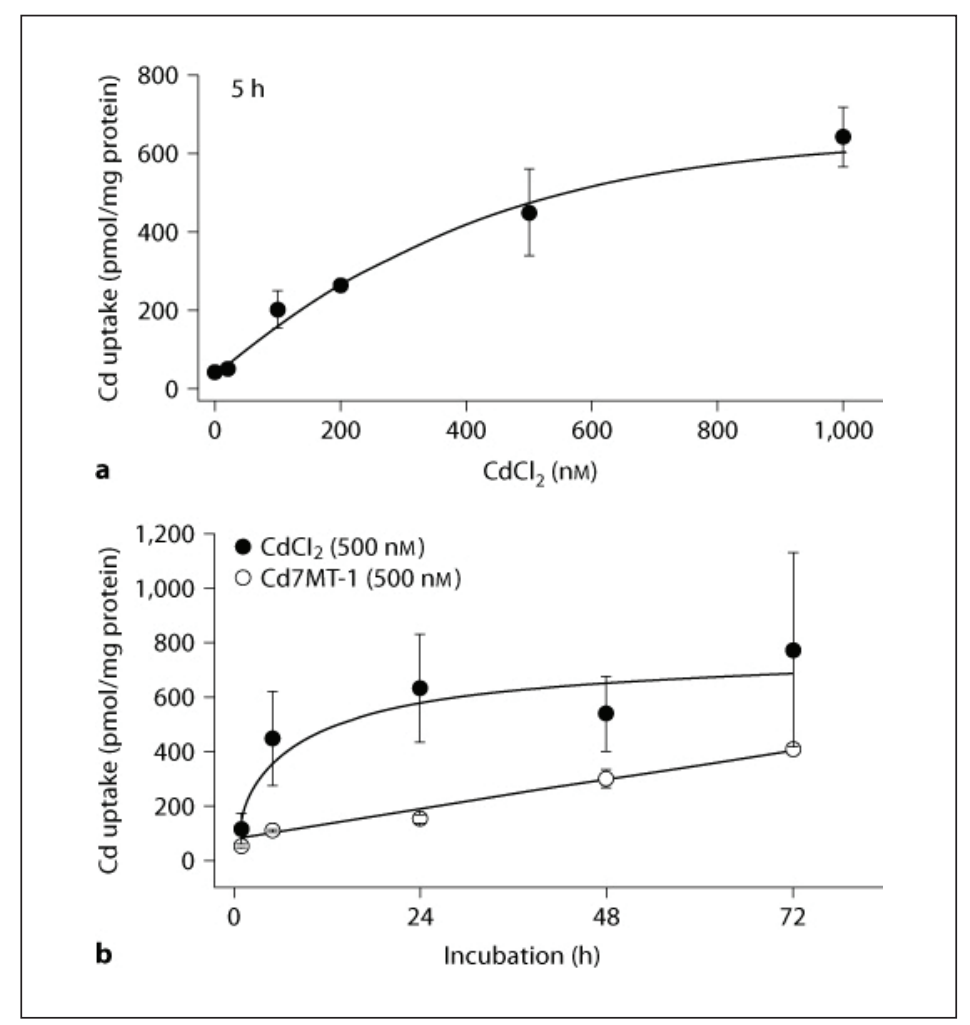

Fig. 1. Intracellular accumulation of $\mathrm{Cd}$ in human kidney tubular cell cultures is dependent on concentration (a) and incubation time (b). a Cells were grown until confluence and incubated at $37^{\circ} \mathrm{C}$ in $\alpha$-MEM medium with different $\mathrm{CdCl}_{2}$ concentrations $(0,20,100,200$, and $500 \mathrm{nM})$ for $5 \mathrm{~h}$. Cd accumulation in the tubular cells was saturable, with a maximal cellular uptake of $641 \pm 76 \mathrm{pmol} \mathrm{Cd} / \mathrm{mg}$ protein. $\mathbf{b}$ Confluent cells were incubated with $500 \mathrm{nM} \mathrm{CdCl}_{2}(\bullet)$ or $500 \mathrm{nM} \mathrm{Cd7MT-1}(\bigcirc)$ for periods of 3, 5, 24, 48, and $72 \mathrm{~h}$. Intracellular accumulation kinetics were clearly different for both. Values are means \pm SEM of triplicate determinations, performed on cells originating from 3 different nephrectomies. In each of these 3 experiments, triplicate determinations ( 3 wells) were performed for each condition.

\section{Effect of $\mathrm{pH}$ and $\mathrm{Zn}$ on Intracellular Cd Accumulation}

To evaluate the effect of $\mathrm{pH}$ on the intracellular $\mathrm{Cd}$ accumulation during exposure to $\mathrm{CdCl}_{2}$, cells were incubated for different periods with $20 \mathrm{nM} \mathrm{CdCl}_{2}$ in glucose-containing HEPES- (pH 7.4) and MES- (pH 5.5) buffered solutions. The intracellular Cd accumulation was significantly higher $(\mathrm{p}<0.05)$ in cells that were incubated in the acidic buffer (fig. $2 a)$.

To determine whether $\mathrm{Zn}$ would affect $\mathrm{Cd}$ accumulation, cultures were incubated with $5 \mu \mathrm{MnCl}_{2}$ (1 h before and during the whole $\mathrm{CdCl}_{2}$ incubation period). The intracellular $\mathrm{Cd}$ concentration decreased from $632 \pm 199$ to $149 \pm 100 \mathrm{pmol} / \mathrm{mg}$ protein in the presence of $\mathrm{Zn}^{2+}$ (fig. 2b).

\section{Possible Involvement of DMT Proteins in Cellular Cd Uptake}

The observation that the accumulation of $\mathrm{Cd}^{2+}$ in the tubular cells is $\mathrm{pH}$ dependent and dramatically affected by the presence of other divalent cations (such as $\mathrm{Zn}$ ) points to a possible important contribution of DMT proteins to the uptake of Cd into the cells. As DMT-1 is expressed in the kidney [20], it was investigated by quantitative real-time RT-PCR analysis whether exposure of the tubular cells to $\mathrm{CdCl}_{2}$ goes along with an upregulation of the DMT1 gene expression. 


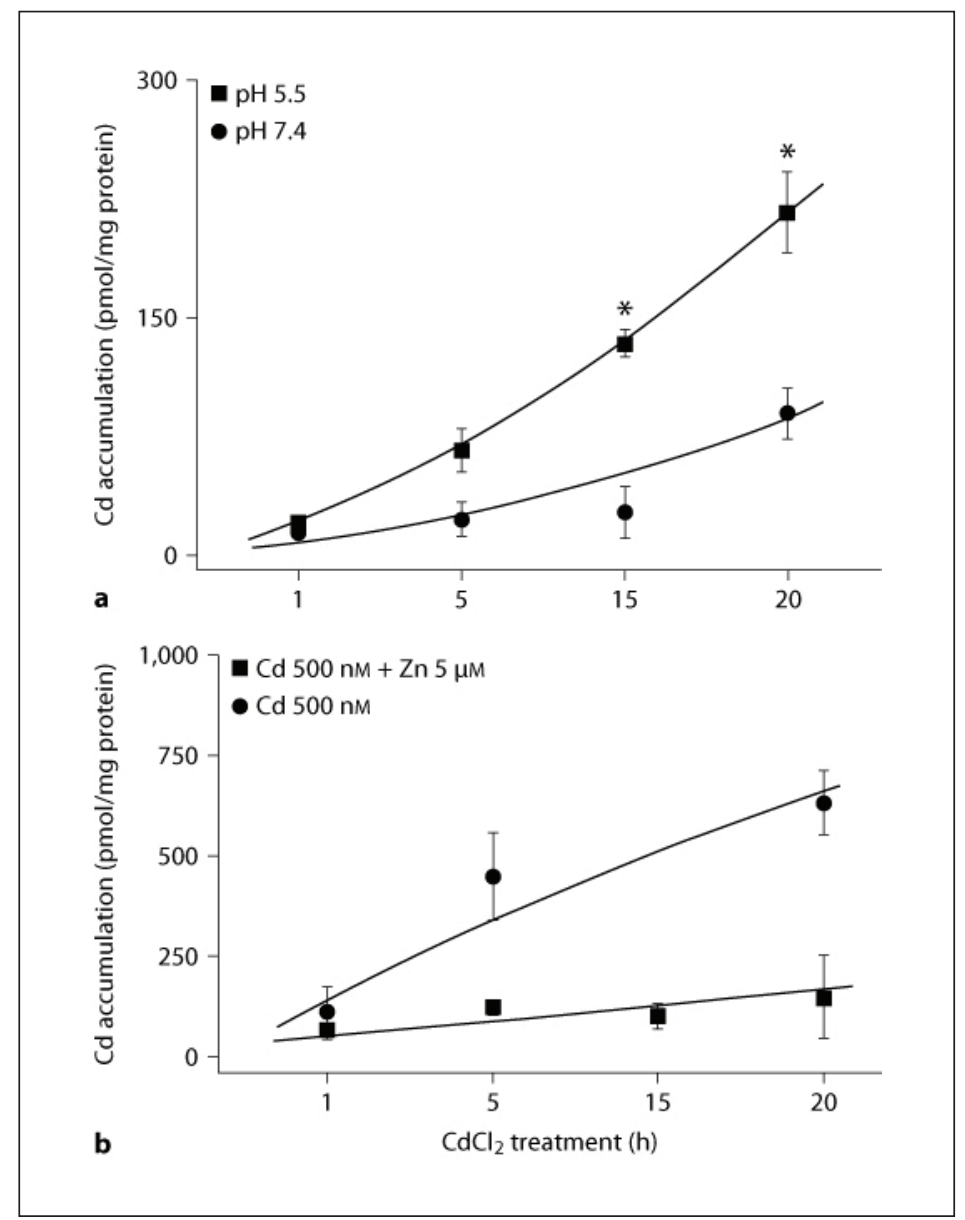

Fig. 2. Intracellular accumulation of $\mathrm{Cd}$, added to the cell culture medium as $\mathrm{CdCl}_{2}$, is $\mathrm{pH}$ dependent (a) and inhibited by $\mathrm{Zn}$ (b). a Confluent cells were incubated in glucose-containing buffered solution of $\mathrm{pH}$ 5.5 or $7.4 ; 20 \mathrm{nM} \mathrm{CdCl}_{2}$ was added for indicated time periods. Mean values of $\mathrm{Cd}^{2+}$ accumulation at $\mathrm{pH}$ 5.5 and 7.4 were significantly different from each other for incubation times 15 and $20 \mathrm{~h}$. b Confluent cells were incubated with $500 \mathrm{nM} \mathrm{CdCl}_{2}$ either in the presence or in the absence of $5 \mu \mathrm{M} \mathrm{ZnCl}_{2}$. The intracellular $\mathrm{Cd}^{2+}$ accumulation was significantly inhibited by the presence of $\mathrm{Zn}$. Each data point represents means \pm SEM of 3 wells derived from tissue of the same nephrectomy. ${ }^{*} \mathrm{p}<0.05$.

After $5 \mathrm{~h}$ of $\mathrm{CdCl}_{2}$ treatment, mRNA expression level of the gene encoding DMT-1 was not different from that in cultured human renal cells at control conditions (absence of $\mathrm{Cd}$; fig. 3, open column). However, long-term (24-72 h) exposure to $500 \mathrm{nM} \mathrm{CdCl}_{2}$ resulted in a significant ( $\mathrm{p}<0.05$ vs. control) increase in the DMT-1/GAPDH ratio.

\section{$\mathrm{CdCl}_{2}$-Induced Effects on the Expression of Genes Relevant to Nephrotoxic Processes}

In this part of the study, we investigated whether inorganic $\mathrm{CdCl}_{2}$ had an effect on the gene expression of key proteins in pathways relevant to nephrotoxic processes: MT-1 and $\mathrm{HO}-1$ as protectors against oxidative stress; and $\mathrm{Bax}$ and $\mathrm{Bcl}-2$ as pro- and anti-apoptotic genes, respectively. In addition, we examined in which way pre-incubation of the cells with an anti-oxidative agent (ebselen) influenced the expression of these genes.

Treatment of the cells with $\mathrm{CdCl}_{2}$ at physiologically relevant concentrations $(20,100$, 200,500 , and $1,000 \mathrm{nM}$ ) during $5 \mathrm{~h}$ resulted in a concentration-dependent increase of MT-1 


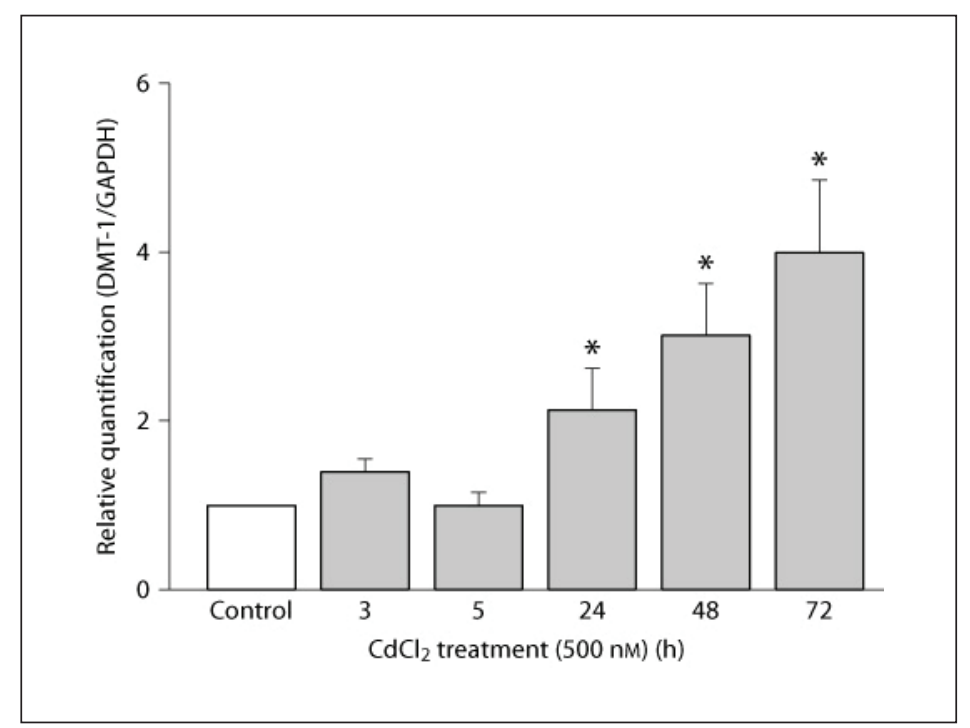

Fig. 3. Expression of DMT-1 (DMT-1/GAPDH) mRNA in human tubular cells affected by $\mathrm{CdCl}_{2}$ exposure. Confluent primary cultured cells were treated with $500 \mathrm{nM} \mathrm{CdCl}_{2}$ during 0 (control), 3, 5, 24, 48, and $72 \mathrm{~h}$. DMT-1 and GAPDH mRNA levels were quantified by quantitative real-time RT-PCR; values obtained from untreated (control) cells were set to 1. Relative DMT-1 expression (DMT-1/GAPDH) is significantly upregulated starting at $24 \mathrm{~h} \mathrm{CdCl}_{2}$ incubation. Data represent means $\pm \mathrm{SEM}$ of triplicate experiments on cells originating from the same nephrectomy. ${ }^{*} \mathrm{p}<0.05$ as compared to control.

mRNA levels, ranging from a 3-fold increase at $100 \mathrm{nM} \mathrm{CdCl}_{2}$ up to a 140 -fold increase at a concentration of $1,000 \mathrm{nM} \mathrm{CdCl}_{2}$ (fig. $4 \mathrm{a}$, open columns). When the cells were treated with $10 \mu \mathrm{M}$ ebselen for $1 \mathrm{~h}$, prior to $\mathrm{CdCl}_{2}$ administration, a significantly $(\mathrm{p}<0.05)$ lower $\mathrm{Cd}^{2+}-$ induced production of MT-1 mRNA was observed. Although production of MT-1 was not completely abolished in any condition, at the highest $\mathrm{CdCl}_{2}$ concentration $(1,000 \mathrm{nM})$, mRNA levels of MT-1 were up to 3 times lower in ebselen-treated cells as compared to the non-treated cultures (fig. $4 \mathrm{a}$, closed columns). With regard to the temporal effect of $\mathrm{CdCl}_{2}$ exposure on the MT-1 gene expression, a peak level was observed after $5 \mathrm{~h}$ of exposure of the cells to culture medium containing $500 \mathrm{nM} \mathrm{CdCl}_{2}$. With longer incubation periods, MT-1 mRNA expression again decreased reaching baseline levels after $48 \mathrm{~h}$ of treatment (fig. 4b).

Similar to MT-1, induction of HO-1 is an important cellular response and a well-recognized biomarker for oxidative stress. Treatment of the cells with $\mathrm{CdCl}_{2}$ for $5 \mathrm{~h}$ significantly and dose-dependently ( $\mathrm{CdCl}_{2}>200 \mathrm{nM}$ ) upregulated (4-fold) the expression of HO-1 mRNA in human tubular cells as compared to controls (fig. 5a). This upregulation of HO-1 was completely prevented by pre-incubation of the cells with $10 \mu \mathrm{M}$ ebselen for $1 \mathrm{~h}$. With regard to the temporal effect, relative expression of $\mathrm{HO}-1 \mathrm{mRNA}$ after exposure to $\mathrm{CdCl}_{2}$ for more than $5 \mathrm{~h}$ was not significantly different anymore from cells not incubated with $\mathrm{CdCl}_{2}$ (fig. $5 \mathrm{~b}$ ).

In comparison to controls, the Bax mRNA level was significantly higher when cells were exposed to $500 \mathrm{nM} \mathrm{CdCl}_{2}$ for longer time periods (24-72 h). In contrast, the expression of Bcl-2 mRNA significantly decreased during this period. As a result, the Bax/Bcl-2 mRNA ratio significantly shifted in favor of Bax, yielding values of 1.4, 2.3, and 4.5 versus controls (set at 1.0) after 24,48 , and $78 \mathrm{~h}$, respectively (fig. 6). No significant effect was observed after a short $(<24 \mathrm{~h})$ exposure to $\mathrm{CdCl}_{2}$. 


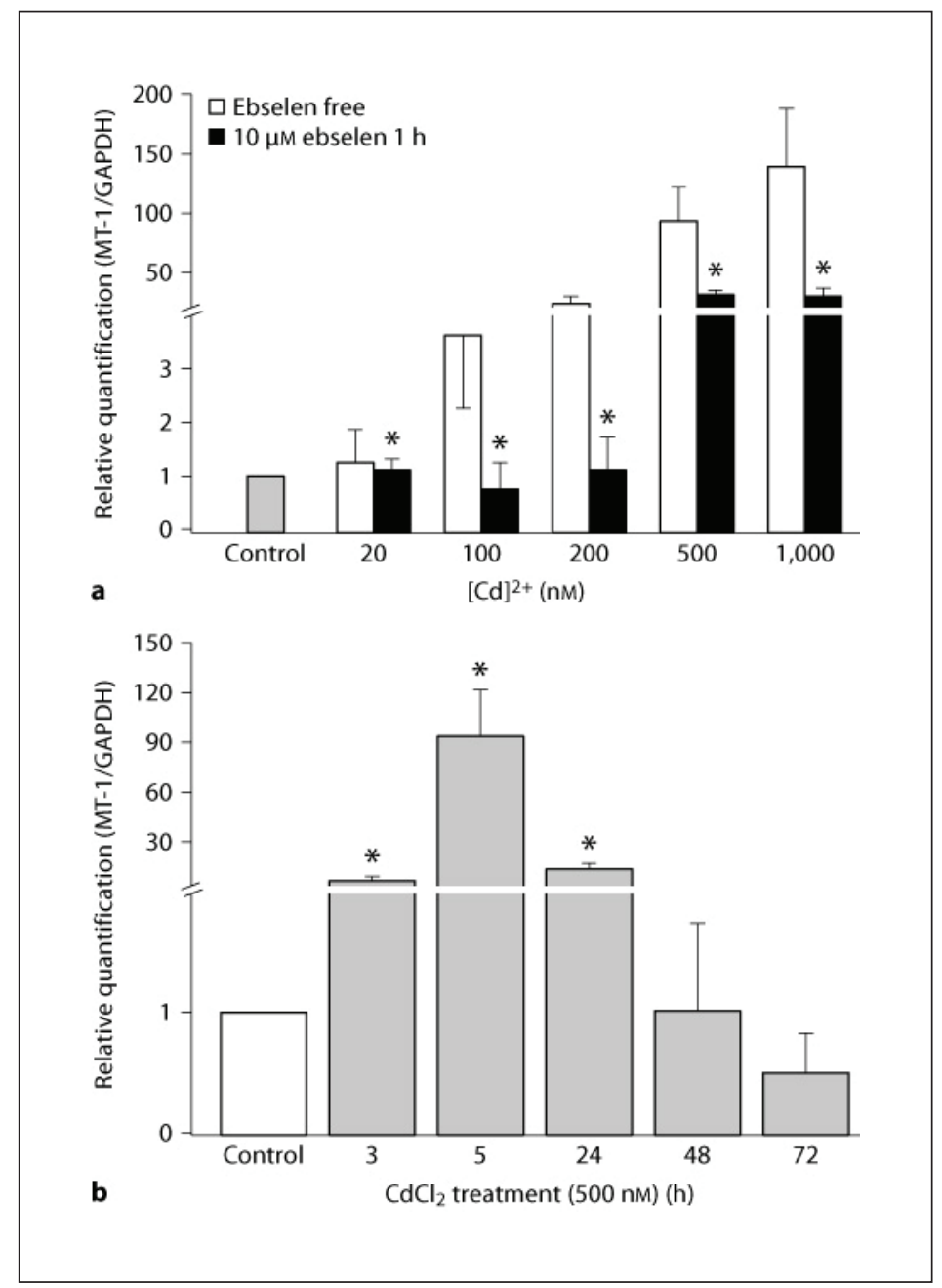

Fig. 4. Expression of MT-1 mRNA in human tubular cells. a Relative expression of MT-1 (MT-1/GAPDH) mRNA in tubular cells treated for $5 \mathrm{~h}$ with different $\mathrm{CdCl}_{2}$ concentrations $(20-1,000 \mathrm{nM})$, either or not pre-incubated with $10 \mu \mathrm{M}$ ebselen. MT-1 mRNA was upregulated by $\mathrm{CdCl}_{2}$. Upregulation was significantly prevented by ebselen pre-treatment. b Time course (3-72 h) of relative MT-1 (MT-1/GAPDH) mRNA expression in tubular cells after exposure to $\mathrm{CdCl}_{2}(500 \mathrm{nM})$. MT-1 mRNA expression was significantly upregulated versus control during the short incubation times only. Columns represent means \pm SEM of triplicate experiments on cells originating from the same nephrectomy as in figure $3 .{ }^{*} \mathrm{p}<0.05$.

Cd7MT-1-Induced Effects on the Expression of Genes Relevant to Nephrotoxic Processes MT-1 mRNA expression of cells incubated with $500 \mathrm{nM} \mathrm{Cd7MT-1} \mathrm{remained} \mathrm{below} \mathrm{base-}$ line levels (data not shown). Moreover, in contrast to $\mathrm{CdCl}_{2}$, the presence of Cd7MT-1 resulted in a reduction in HO-1 mRNA levels at 24,48 , and $72 \mathrm{~h}$ (fig. $7 \mathrm{a}$ ). Additionally, whereas $\mathrm{CdCl}_{2}$ treatment significantly shifted the Bax/Bcl-2 mRNA ratio in favor of Bax, Cd7MT-1 treatment significantly shifted the Bax/Bcl-2 mRNA ratio in favor of the anti-apoptotic Bcl2 , yielding values of 1.4, 2.3, and 4.5 versus controls (set at 1.0 ) after 24,48 , and $78 \mathrm{~h}$, respectively (fig. 7b). 

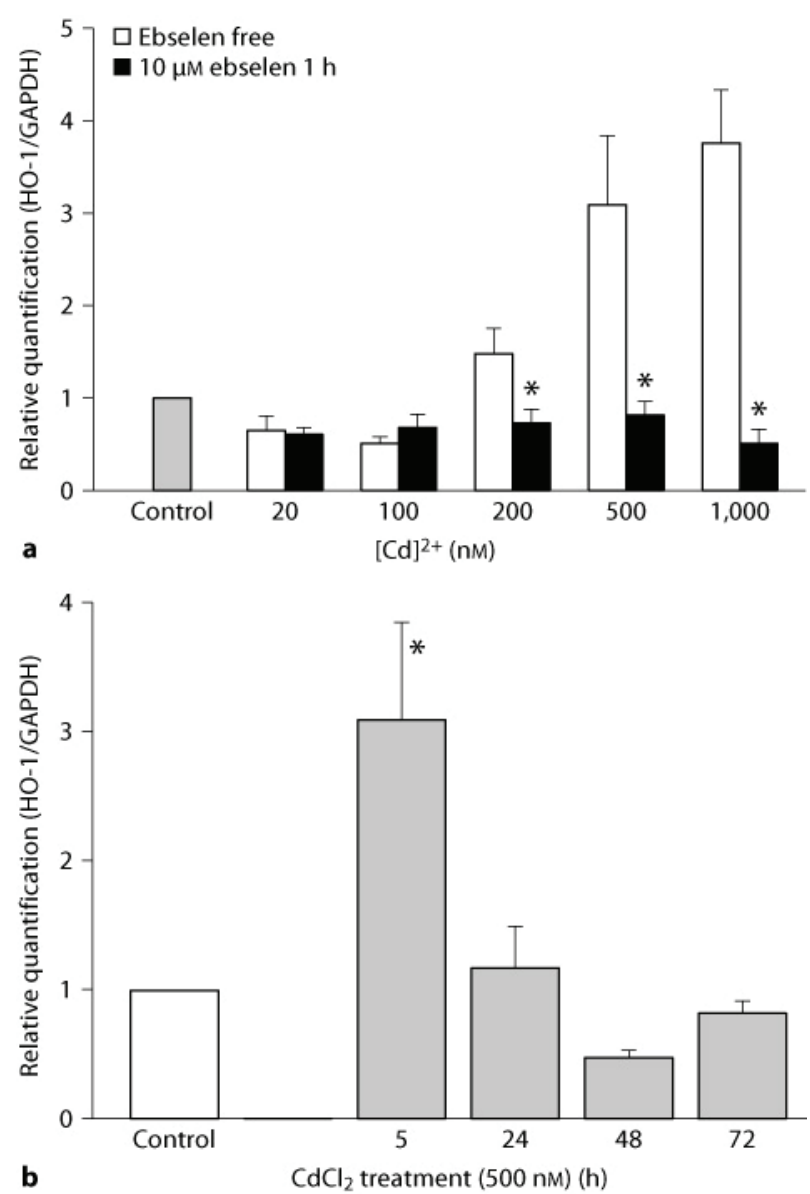

Fig. 5. Expression of HO-1 mRNA in human tubular cells. a Relative expression of HO-1 (HO-1/GAPDH) mRNA in tubular cells treated for $5 \mathrm{~h}$ with different $\mathrm{CdCl}_{2}$ concentrations $(2-1,000 \mathrm{nM})$, either or not preincubated with $10 \mu \mathrm{M}$ ebselen. HO-1 mRNA was upregulated by $\mathrm{CdCl}_{2}$. Upregulation was significantly prevented by ebselen pre-treatment. b Time course (3-72 h) of relative HO-1 (HO-1/GAPDH) mRNA expression in tubular cells after exposure to $\mathrm{CdCl}_{2}(500 \mathrm{nM})$. HO-1 mRNA expression was significantly upregulated versus control after $5 \mathrm{~h}$ of incubation, while baseline expression was seen for the longer incubation periods. Columns represent means \pm SEM of triplicate experiments on cells originating from the same nephrectomy as in figures 3 and $4 .{ }^{*} \mathrm{p}<0.05$.

\section{Discussion}

In the present study, the renal tubular handling of $\mathrm{Cd}^{2+}$ was investigated by exposing primary human tubular cell cultures to physiologically relevant concentrations $(20-1,000$ $\mathrm{nM})$ of $\mathrm{Cd}^{2+}$ (administered as $\left.\mathrm{CdCl}_{2}\right) \cdot \mathrm{Cd}^{2+}$ accumulated into those cells in a concentrationand time-dependent manner. Furthermore, (time-dependent) cellular accumulation of $\mathrm{Cd}^{2+}$ was different from the cellular accumulation of $\mathrm{Cd}$ bound to metallothionein. Indeed, in contrast to the quick plateauing of $\mathrm{Cd}$ administered as $\mathrm{CdCl}_{2}, \mathrm{Cd}$ accumulation when administered as Cd7MT-1 steadily increased over time during $72 \mathrm{~h}$ of treatment, suggesting different routes of uptake for both compounds. 


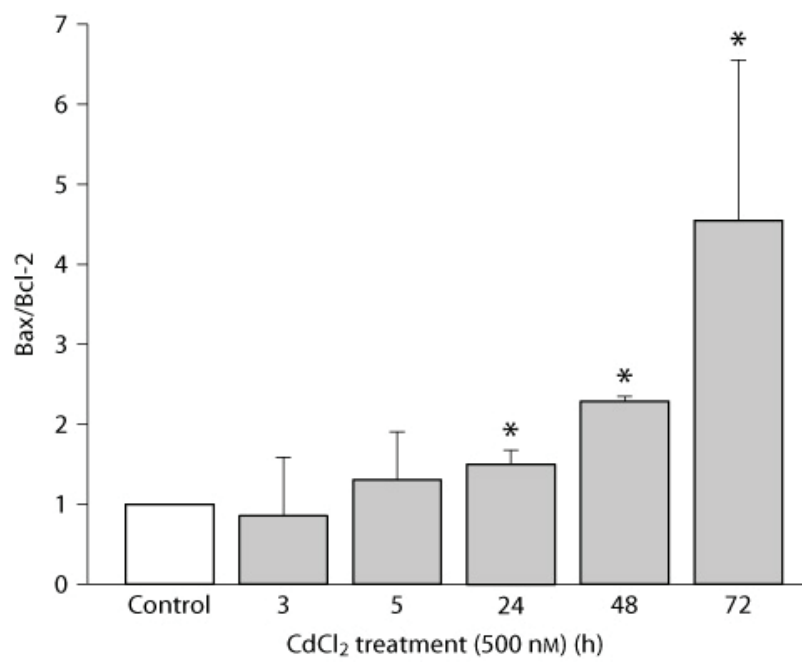

Fig. 6. $\mathrm{Bax} / \mathrm{Bcl}-2$ ratio in human tubular cells chronically treated with $\mathrm{CdCl}_{2}$. Confluent tubular cell cultures were exposed to $500 \mathrm{nM} \mathrm{CdCl}_{2}$ for different time periods (3-72 h). $\mathrm{CdCl}_{2}$ treatment during $24 \mathrm{~h}$ or longer significantly increased the Bax/Bcl-2 ratio versus untreated control. Ratios of Bax/Bcl-2 mRNA levels were calculated from relative expression ratios (to GAPDH) of both genes. The results are means \pm SEM of triplicate experiments on cells originating from the same nephrectomy. ${ }^{*} \mathrm{p}<0.05$.

Consensus exists in the literature regarding the uptake of Cd7MT-1 by the renal cell, and one may assume that Cd7MT-1 is internalized at the apical membrane of renal cells, especially proximal tubular cells, via RME [21]. RME of proteins has previously been studied in the primary human tubular cell culture model proposed here [19]. We found that this process, in line with the in vivo situation, occurs in cells originating from the proximal part of the tubule, while it was absent in cells originating from the more distal parts of the nephron. This result together with the notion that uptake of Cd7MT-1 is not saturable at the concentration under study allows us to presume that the uptake of Cd7MT-1 in our cell cultures also took place through RME by the proximal tubular cells.

In contrast to Cd7MT-1, the uptake pathway of $\mathrm{Cd}^{2+}$ is much less known. Cd is a nonessential metal and therefore most likely uses cellular entry pathways of other (essential) metals such as iron $(\mathrm{Fe})$ and $\mathrm{Zn}$. The finding that in our cell culture model, Cd accumulation in the cells was significantly higher at $\mathrm{pH} 5.5$ as compared to $\mathrm{pH} 7.4$, points to the involvement of DMT-1 in the cellular uptake of Cd $[22,23]$. This is further supported by our data showing that long-term exposure to $\mathrm{CdCl}_{2}$ (fig. 3) goes along with a significant and timedependent increase of the DMT-1 mRNA expression. An in-detail study of DMT-1 expression in the kidney indicated that, next to its lysosomal presence in the proximal tubule, DMT1 is also present at the apical membrane of cells in the thick ascending limb and more distal parts of the nephron [20]. Preliminary investigations of our group on $\mathrm{Cd}^{2+}$ uptake in pure cultures of distal tubular cells revealed that $\mathrm{Cd}^{2+}$ indeed is taken up by distal tubular cells as well. This is in line with a study of Olivi et al. [24] reporting DMT-1-mediated uptake of Cd (administered as $\mathrm{CdCl}_{2}$ ) into MDCK cells, a cell line originating from the distal tubular part of the nephron.

Although DMT-1 primarily is an Fe-transporting molecule, a recent study identified DMT-1 as a Zn-transporting molecule as well [25]. Therefore, the dramatic inhibition of cel- 


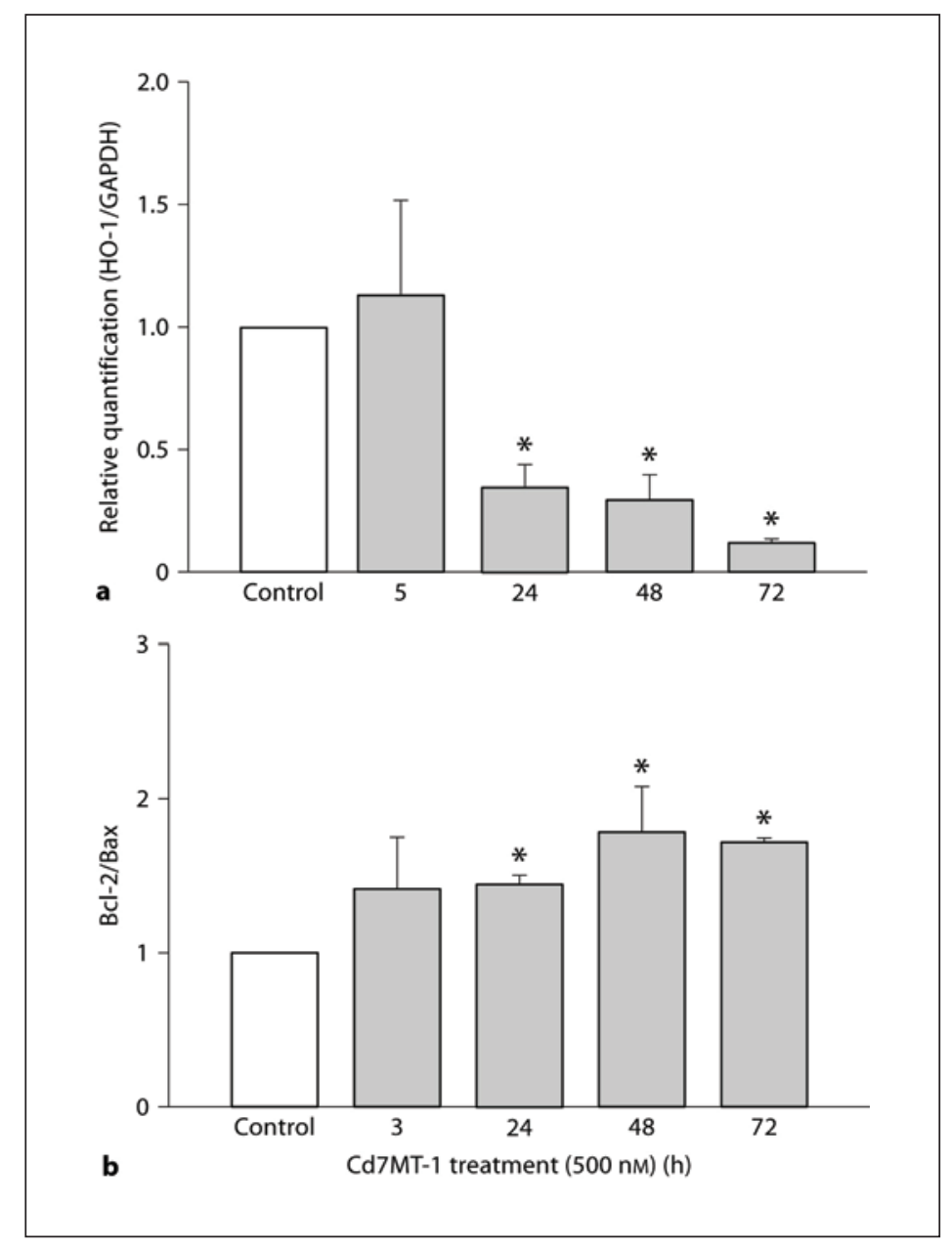

Fig. 7. The relative expression of the genes associated with the effects of Cd7MT-1. a Time course (3-72 h) of relative HO-1 (HO-1/GAPDH) mRNA expression in tubular cells after exposure to Cd7MT-1 (500 nM). HO-1 mRNA expression was significantly downregulated versus control for 24, 48, and $72 \mathrm{~h}$ incubation periods. b Cd7MT-1 treatment during 24 h or longer significantly increased the Bcl-2/Bax ratio versus untreated control. Ratios of Bcl-2/Bax mRNA levels were calculated from relative expression ratios (to GAPDH) of both genes. The results are means \pm SEM of triplicate experiments on cells originating from one nephrectomy (same as in figure 6). ${ }^{*} \mathrm{p}<0.05$.

lular Cd accumulation in the presence of Zn may also be indicative for a role of DMT-1 in cellular Cd transport. However, it also points to the potential contribution of other (Zn) transporters such as those of the ZIP family [26]. The further unraveling of the pathways involved in cellular $\mathrm{Cd}$ accumulation in different parts of the nephron would be an interesting challenge for future investigations.

In conclusion, the results described above make clear that the handling of the same concentrations of $\mathrm{Cd}$ in either its inorganic $\left(\mathrm{CdCl}_{2}\right)$ or organic form (Cd7MT-1) by human tubular kidney cells is very different. These different kinetics point to different uptake pathways, which end up in different intracellular concentrations and most probably in a different intracellular localization as well. This incited us to check whether differences in cellular handling of $\mathrm{Cd}$ also result in different effects on the expression of genes of which the protein products are known to play a role in cellular toxicity. 
Unlike Fe and copper $(\mathrm{Cu}), \mathrm{Cd}$ is not a Fenton metal and thus does not generate free radicals by itself. Hence, nowadays there is increasing evidence that ROS are generated in the presence of $\mathrm{Cd}$ [27] and that several proteins such as metallothioneins and heme-oxygenases may act as early protective tools against oxidative stress. Our results are in line with this as they show that acute exposure $(5 \mathrm{~h})$ to high doses of $\mathrm{CdCl}_{2}$ stimulates production of MT-1 mRNA up to 140 -fold as compared to controls (no exposure to $\mathrm{CdCl}_{2}$ ). These results are in agreement with literature data showing increased transcription of MT-1 genes in response to acute exposure to particular metals. Moreover, in previous studies, it has been found that overexpression of MT-1 mRNA levels correlates well with increased production of the MT-1 protein, suggesting that transcription rather than translation determines the $\mathrm{Cd}^{2+}$-induced upregulation of MT-1 [28].

Together with MT-1, the induction of HO-1 has been established as a defense mechanism against oxidative stress. HO-1 expression increases following exposure to a wide variety of cellular stressors. HO-1 mRNA expression showed a similar temporal pattern as that seen for MT-1 mRNA, as the mRNA levels of HO-1 rapidly increased after an acute 5-hour exposure to $\mathrm{CdCl}_{2}$, after which they again decreased to baseline values after longer exposure periods (24-72 h).

In contrast to $\mathrm{CdCl}_{2}$, culturing of our cells in Cd7MT-1-containing cell culture medium did not result in upregulation of HO-1 or MT-1 mRNA expression. As a next step, the expression of MT-1 and HO-1 mRNA in response to $\mathrm{Cd}^{2+}$ exposure was measured after pre-incubating the cells with ebselen. Ebselen [2-phenyl-1,2-benzisoselenazol-3(2H)-one] is a selenium-containing compound which has been shown to exhibit anti-oxidant, anti-nociceptive, neuroprotective and anti-inflammatory properties in various experimental models [29-31]. Thus, the rationale for pre-treating cells with ebselen was that if cellular upregulation of MT-1 and HO-1 mRNA protects cells against $\mathrm{Cd}^{2+}$-induced oxidative stress, a reduced upregulation of both genes must reasonably be expected in the presence of ebselen. Results indicated that pre-incubation with ebselen indeed prevented the upregulation of $\mathrm{HO}-1$ and MT-1 mRNA during $\mathrm{Cd}^{2+}$ exposure.

During the last decade, studies at the cellular level indicated that Cd may induce various biochemical changes associated with apoptosis [32]. Different families of proteins have been identified to play an important role in the apoptotic process. Of these, Bcl-2, an intracellular membrane-associated protein family, functions to inhibit apoptosis, whereas the Bax and $\mathrm{BH} 3$ families promote apoptosis $[33,34]$. Hence, a shift in the Bax/Bcl-2 balance may modulate the cellular function either to pro- or to anti-apoptotic processes.

The present study demonstrates that the Bax/Bcl-2 gene expression ratio is shifted towards the apoptotic pathway when cells are treated with $\mathrm{CdCl}_{2}$ (fig. 6). Interestingly, the temporal increase in the $\mathrm{Bax} / \mathrm{Bcl}-2$ gene expression ratio at $24-72 \mathrm{~h}$ of incubation went along with the normalization (end of upregulation) of both the MT-1 and HO-1 mRNA expression. In this context, the observation that, in the presence of Cd7MT-1, the cellular response in contrast to $\mathrm{CdCl}_{2}$ is in favor of Bcl-2 mRNA expression is interesting and in agreement with previous studies obtained on renal cells of porcine origin, in which overexpression of Bcl-2 mRNA completely inhibited Cd-induced apoptosis [35].

In summary, in the presence of physiologically relevant Cd concentrations, tubular accumulation of the element in its inorganic form is different from that of Cd7MT-1. Furthermore, the tubular accumulation of inorganic $\mathrm{Cd}$ induces genes of which the protein products may play a role in Cd-associated renal toxicity, while this is not the case for Cd7MT-1. Indeed, whereas exposure to $\mathrm{CdCl}_{2}$ induces an increase in MT- 1 and HO-1 mRNA, expression of the genes remained below baseline levels in the presence of Cd7MT-1. Moreover, in contrast to Cd7MT-1, cellular exposure to $\mathrm{CdCl}_{2}$ does result in an upregulation of pro-apoptotic genes. Finally, this study demonstrates that, in combination with a set of appropriate analytical 
techniques, our human primary cell culture system offers an excellent model to study the characteristics and toxicological consequences of cellular uptake of heavy metals at the level of the kidney.

\section{Acknowledgments}

This work would not have been possible without the generous cooperation of Dr. Braekman (University Hospital, Brussels), Dr. Verkoelen and Dr. Asselman (Erasmus Medical Center, Rotterdam), Dr. Dekuyper (AZ Maria Middelares, Ghent) and Prof. Oosterlinck (University Hospital, Ghent).

This work was funded by a BOF ('Bijzonder Onderzoeksfonds' - University of Antwerp) Bilateral Scientific Cooperation Programme between Flanders and Romania. Dr. Anja Verhulst is a postdoctoral fellow of the Fund for Scientific Research Flanders (FWO).

Dr. Dana Cucu acknowledges the POSDRU/89/1.5/S/60746 program.

\section{Disclosure Statement}

The authors confirm that there are no conflicts of interest.

\section{References}

1 Thevenod F: Nephrotoxicity and the proximal tubule. Insights from cadmium. Nephron Physiol 2003;93:87-93.

2 Zalups RK, Ahmad S: Molecular handling of cadmium in transporting epithelia. Toxicol Appl Pharmacol 2003;186:163-188.

3 Elinder CG, Lind B, Kjellstrom T, Linnman L, Friberg L: Cadmium in kidney cortex, liver, and pancreas from Swedish autopsies. Estimation of biological half time in kidney cortex, considering calorie intake and smoking habits. Arch Environ Health 1976;31:292-302.

4 Lewis GP, Coughlin LL, Jusko WJ, Hartz S: Contribution of cigarette smoking to cadmium accumulation in man. Lancet 1972;1:291-292.

5 Diamond GL, Goodrum PE, Felter SP, Ruoff WL: Gastrointestinal absorption of metals. Drug Chem Toxicol 1998;21:223-251.

6 Habeebu SS, Liu J, Klaassen CD: Cadmium-induced apoptosis in mouse liver. Toxicol Appl Pharmacol 1998;149:203-209.

7 Nordberg GF: Cadmium and health in the 21st century - historical remarks and trends for the future. Biometals 2004;17:485-489.

8 Svartengren M, Elinder CG, Friberg L, Lind B: Distribution and concentration of cadmium in human kidney. Environ Res 1986;39:1-7.

9 Nordberg GF: Historical perspectives on cadmium toxicology. Toxicol Appl Pharmacol 2009;238: $192-200$.

10 Lauwerys R, Roels H, Regniers M, Buchet JP, Bernard A, Goret A: Significance of cadmium concentration in blood and in urine in workers exposed to cadmium. Environ Res 1979;20:375-391.

11 Minoia C, Sabbioni E, Apostoli P, Pietra R, Pozzoli L, Gallorini M, Nicolaou G, Alessio L, Capodaglio E: Trace element reference values in tissues from inhabitants of the European community. I. A study of 46 elements in urine, blood and serum of Italian subjects. Sci Total Environ 1990;95:89-105.

12 Jarup L, Berglund M, Elinder CG, Nordberg G, Vahter M: Health effects of cadmium exposure - a review of the literature and a risk estimate. Scand J Work Environ Health 1998;24(suppl 1):1-51.

13 Suwazono Y, Sand S, Vahter M, Filipsson AF, Skerfving S, Lidfeldt J, Akesson A: Benchmark dose for cadmium-induced renal effects in humans. Environ Health Perspect 2006;114:1072-1076. 
14 Barbier O, Jacquillet G, Tauc M, Poujeol P, Cougnon M: Acute study of interaction among cadmium, calcium, and zinc transport along the rat nephron in vivo. Am J Physiol Renal Physiol 2004;287:F1067F1075.

15 Gennari A, Cortese E, Boveri M, Casado J, Prieto P: Sensitive endpoints for evaluating cadmiuminduced acute toxicity in LLC-PK1 cells. Toxicology 2003;183:211-220.

16 Lijnen P, Staessen J, Fagard R, Amery A: Effect of cadmium on transmembrane $\mathrm{Na}^{+}$and $\mathrm{K}^{+}$transport systems in human erythrocytes. Br J Ind Med 1991;48:392-398.

17 Kazantzis G: Cadmium, osteoporosis and calcium metabolism. Biometals 2004;17:493-498.

18 Savolainen H: Cadmium-associated renal disease. Ren Fail 1995;17:483-487.

19 Verhulst A, D'Haese PC, De Broe ME: Inhibitors of HMG-COA reductase reduce receptor-mediated endocytosis in human kidney proximal tubular cells. J Am Soc Nephrol 2004;15:2249-2257.

20 Ferguson CJ, Wareing M, Ward DT, Green R, Smith CP, Riccardi D: Cellular localization of divalent metal transporter DMT-1 in rat kidney. Am J Physiol Renal Physiol 2001;280:F803-F814.

21 Abouhamed M, Wolff NA, Lee WK, Smith CP, Thevenod F: Knockdown of endosomal/lysosomal divalent metal transporter 1 by RNA interference prevents cadmium-metallothionein-1 cytotoxicity in renal proximal tubule cells. Am J Physiol Renal Physiol 2007;293:F705-F712.

22 Bannon DI, Abounader R, Lees PS, Bressler JP: Effect of DMT1 knockdown on iron, cadmium, and lead uptake in Caco-2 cells. Am J Physiol Cell Physiol 2003;284:C44-C50.

23 Lam-Yuk-Tseung S, Govoni G, Forbes J, Gros P: Iron transport by Nramp2/DMT1: pH regulation of transport by 2 histidines in transmembrane domain 6. Blood 2003;101:3699-3707.

24 Olivi L, Sisk J, Bressler J: Involvement of DMT1 in uptake of Cd in MDCK cells: role of protein kinase C. Am J Physiol Cell Physiol 2001;281:C793-C800.

25 Deng Z, Dailey LA, Soukup J, Stonehuerner J, Richards JD, Callaghan KD, Yang F, Ghio AJ: Zinc transport by respiratory epithelial cells and interaction with iron homeostasis. Biometals 2009;22: 803-815.

26 Lichten LA, Cousins RJ: Mammalian zinc transporters: nutritional and physiologic regulation. Annu Rev Nutr 2009;29:153-176.

27 Thevenod F, Friedmann JM: Cadmium-mediated oxidative stress in kidney proximal tubule cells induces degradation of $\mathrm{Na}+/ \mathrm{K}(+)$-ATPase through proteasomal and endo-/lysosomal proteolytic pathways. FASEB J 1999;13:1751-1761.

28 Zalups RK, Koropatnick J: Temporal changes in metallothionein gene transcription in rat kidney and liver: relationship to content of mercury and metallothionein protein. J Pharmacol Exp Ther 2000; 295:74-82.

29 Chander PN, Gealekman O, Brodsky SV, Elitok S, Tojo A, Crabtree M, Gross SS, Goligorsky MS: Nephropathy in Zucker diabetic fat rat is associated with oxidative and nitrosative stress: prevention by chronic therapy with a peroxynitrite scavenger ebselen. J Am Soc Nephrol 2004;15:2391-2403.

30 Meotti FC, Borges VC, Zeni G, Rocha JB, Nogueira CW: Potential renal and hepatic toxicity of diphenyl diselenide, diphenyl ditelluride and ebselen for rats and mice. Toxicol Lett 2003;143:9-16.

31 Nogueira CW, Quinhones EB, Jung EA, Zeni G, Rocha JB: Anti-inflammatory and antinociceptive activity of diphenyl diselenide. Inflamm Res 2003;52:56-63.

32 Robertson JD, Orrenius S: Molecular mechanisms of apoptosis induced by cytotoxic chemicals. Crit Rev Toxicol 2000;30:609-627.

33 Adams JM, Cory S: Bcl-2-regulated apoptosis: mechanism and therapeutic potential. Curr Opin Immunol 2007;19:488-496.

34 Fernandez-Luna JL: Apoptosis regulators as targets for cancer therapy. Clin Transl Oncol 2007;9: $555-562$.

35 Ishido M, Ohtsubo R, Adachi T, Kunimoto M: Attenuation of both apoptotic and necrotic actions of cadmium by BCL-2. Environ Health Perspect 2002;110:37-42. 